\title{
Liberal Politics in Wartime Russia: An Analysis of the Progressive Bloc
}

My objective in this article is to examine the purpose and the performance of the Progressive Bloc, the wartime majority coalition of Russia's Fourth State Duma. ${ }^{1}$ My analysis, in turn, should promote a more sophisticated understanding of the political behavior of Russia's moderates, and in particular of Russia's liberals, during the final years of crisis for the tsarist regime.

Although cooperation among the moderate caucuses of the Duma was increasing before the war, the formation of the Bloc in August 1915 resulted largely from a serious decline in Russia's military position. The Galician retreat, which enabled the German armies to occupy large sections of Russia's populous western provinces, confirmed to the parliamentary leaders that the government was incapable of meeting the needs of a country at war. The Duma represented the only national center of authority, other than the inept and discredited government. To most moderates, it could play a critical role by helping coordinate vigorous mobilization of the empire's resources, both natural and human. Furthermore, at a time of panic and despair, by manifesting unity and cooperation the Duma could boost the morale and confidence of the army and the beleaguered populace. The formation of a majority coalition, united around a pertinent legislative program, could demonstrate to the government and to the public that the Duma was capable of playing a constructive wartime role. It conld eliminate the pretext which the government had used to adjourn the Duma earlier - that it was disorganized and ineffective, and that it therefore could not remain in session during periods of national crisis. ${ }^{2}$

The idea of a left-center coalition in the Duma was discussed as early as January 1914, on the initiative of the Progressists. A. I. Konovalov in particular saw a coalition as a means of recovering prestige for the Duma among the

1. The Bloc consisted of six Duma caucuses and comprised about 241 of the 407 deputies in the Duma in August 1915. The Kadets, Progressists, and Left Octobrists formed the "liberal" segment of the Bloc, at least on most issues, while the Centrists, Zemstvo Octobrists, and Progressive Nationalists comprised the more conservative wing. The Nationalist members divided over participation in the Bloc; the group that joined called itself "Progressive Nationalists."

2. During the first year of the war the Duma had met only on July 26, 1914, when its deputies pledged nearly full support for the war, and during January 27-29, 1915, when its activity consisted mainly of passing the budget. All dates are Old Style. 
workers and the more progressive groups in society. ${ }^{3}$ In general the Progressists tried to act as mediators between the Kadets and Octobrists. The latter divided over the issue of cooperating closely with the Kadets, while key Kadet leaders including Miliukov remained reluctant to join forces with the Octobrists. No general agreement was reached prior to the war.

The inability of the government to manage the war effort further reduced the political differences between the Kadets, Progressists, and Left Octobrists, and as soon as the Duma session opened on July 19, 1915, negotiations for a coalition were resumed. ${ }^{4}$ Again the Progressists, especially caucus leaders Konovalov and Ivan Efremov, initiated the talks, but now with the hope that a stable, majority Duma coalition could support the efforts of the public organizations, the Union of Towns, the Union of Zemstvos, and the Central War Industry Committee, which had formed during the early months of the war, and protect them against undue government interference. The leaders of the public organizations, in turn, sought to avoid politics in order to concentrate on the practical tasks of the moment, for example on assisting the resettlement of refugees. The first three issues of the Central War Industry Committee's main publication did not even mention. the Bloc's existence, even though the coalition had formed and published its program that very week. ${ }^{5}$ In addition, with the mood of the country "close to clespair" Konovalov noted that everything must be done to avoid a situation in which the army would lose all hope and in which the masses could find no alternative to force and revolution. ${ }^{6}$

Formulation of a program proved to be a delicate matter. Some conservatives, for example State Council member V. I. Gurko, contended that organizing the country for victory was chiefly the task of the military and the public organizations. Thus a legislative program was not essential, he believed, and risked deeply dividing public opirion. ${ }^{7}$ Left Octobrist S. I.

3. V. Ia. Laverychev, Po tu storonu harrikad (Moscow, 1967), pp. 101-2.

4. See the police report in B. B. Grave, ed., Burshuasia nakanne fevral'skoi revoliutsii (Moscow, 1927), p. 26. hereafter BNFR.

5. See Isvcstiia Tsentral'nago vocmo-promyshlcnnago komitcta (Petrograd). Aug. 24, 29, Sept. 2, 1915. Iaverychev believes that certain Progressists sought unsuccessfully to use the public organizations and provisioning apparatus to wrest political and economic control from the bureaucracy ( $P_{0}$ to storonn barrikad, see esp). $\mathrm{p} .143$ ). In the case of Progressist textile magnate $P$. P. Riabushinsky there is considerable evidence to support this. For example, see $B N F R$, pp. 20-21. For a favorable provincial reaction to the Bloc see the editorial "On the Road to Victory" in the Isiestiia Kostromiskago gubcrnskago scmstza, no. 9, September 1915. which stated that the Duma was capable of bringing order to the country "based on the organization of the people."

6. $B N F R$, p. 30 .

7. N. Lapin, ed., "Progressivnyi blok v 1915-1917 gg.." Krasnyi arkhiz, 50-51 (1932): 122-26, hereafter "Blok." Gurko, a nonaligned member of the State Council, was active in the Bloc, although the Council's most active supporter of the coalition was Left 
Shidlovsky, who was elected chairman of the Bloc, recalled in his memoirs that divisive issues were avoicled in order to concentrate on constructive wartime work. ${ }^{8}$ But Kadet publicist A. A. Kornilov observed that on several occasions it appeared that the negotiations which brought about the coalition and its platform would fail, particularly because of discord over such volatile issues as equal rights for national minority groups."

Despite the unrepresentative nature of the Duma and the Bloc, the coalition agreed on a program which offered at least a token for everyone: for peasants, equalization of rights; for workers, restoration of labor union activities and the labor press: for national minorities, an end to repression and exploitation as well as rectification of several specific grievances. ${ }^{10}$ The program was similar to that of the Kadets, the only caucus in the Bloc to have a clearly definable platform. Nevertheless it represented a genuine compromise in that the Kadets temporarily disavowed their most controversial goals: land reform, equality for Jews, and cabinet responsibility before the Duma. While stressing the patriotic and nonpartisan nature of the Bloc, Kornilov asserted, perhaps defensively, that the coalition and its program constituted an important step along the road of democratization and a step closer to the social ideals of the progressive parties. ${ }^{11}$

But the Bloc's most critical demand, upon which effective implementation of its program depended, was the formation of an efficient and responsive government which could command cooperation and confidence throughout the empire. This meant an end to repressive policies, which only served to increase hostility between classes and nationalities and which therefore both exacerbated an already explosive social situation and promoted divisions at a time when unity throughout the empire was essential. As Pctrogradskii kur'er editorialized, the "real, practical program of the Bloc is only one-the organization of a new ministry of public confidence." 12

The formation of the Bloc and publication of its program created a stir, particularly in the press. Newspapers carried rumors indicating that a ministry of public confidence was imminent, to be headed perhaps by Minister of

Group leader D. D. Grimm. Support in the Council varied from issue to issue, but the Bloc could count on fifty to sixty "sure" votes. Council membership remained at roughly 190 to 196, but absenteeism was rampant, especially among the rightist groups.

8. S. I. Shidlovsky, Vospominanita, 2 vols. (Berlin, 1923), 2:44-45.

9. A. A. Kornilov. Parlamentskii blok (Moscow, 1915), p. 12.

10. The complete program is published in Frank Golder, ed., Documents of Russian History. 1914-1917 (Gloucester. Mass., 1964), pp. 134-36.

11. Kornilov, Parlancntskii blok, pp. 19-20. Kornilov was no doubt sensitive to criticism of the Bloc from several Left Kadets who wanted the party to concentrate on building alliances with the masses and their socialist representatives. Kornilov implied that what occurred in the Duma did not necessarily obstruct this strategy.

12. Cited in Rech', Aug. 31, 1915. 
Agriculture A. Krivoshein or the Octobrist leader A. I. Guchkov. Public organization officials thanked the Bloc for "reviving the public." On August 18 the Moscow City Duma passed a unanimous resolution assuring that "Moscow is convinced that the State Duma at the moment knows how to fulfill the wishes dictated by the country."13 Approximately forty city dumas from throughout the empire also sent resolutions echoing this thought. On August 13 the liberal newspaper Russkiia vedomosti predicted that the State Council, the traditional graveyard of Duma laws, would approve any bill passed by the Duma under current circumstances. On August 25 it called the Bloc's program "broad and pithy" and "touching in one way or another almost all of the urgent national problems raised by the current situation in the country." On August 30 it described the Bloc as the "most significant phenomenon" of the times; on September 1 it drew a parallel to the period of the Crimean War and proclaimed, perhaps wistfully, that Russia needed another "era of great reforms." "The hopes of the country," summarized Duma Centrist V. N. Lvov, "rode with the Duma."14

The mood soon receded, however, as the chairman of the Council of Ministers, Ivan Goremykin, clarified his attitude toward the Bloc. After failing to woo Bloc conservatives into a progovernment coalition, he secured from Tsar Nicholas II a decree to adjourn the Duma on September 3, 1915. Although the Council of Ministers contained several Bloc sympathizers, Goremykin believed that the coalition and its program interested no one but the press. Contrary to the fears of Foreign Minister S. D. Sazonov and others who believed that prorogation would result in bloodshed in the streets and possibly in insurrection, Goremykin declared, "Whether we go along with the bloc or without it is irrelevant for the workers' movement."15 In general Goremykin viewed the Bloc as a powerless body, frightened by disorder and incapable of producing more than general statements of principle. The government hence refused to cooperate with society's leading spokesmen, even in the face of wartime disaster. In the words of Kadet leader P. N. Miliukov, "the extended hand had been rejected," while the liberal Moscow newspaper Utro Rossii editorialized that disbandment of the Duma severely wounded public morale. $^{16}$

13. Chetvertaia gosudarstvennaia duma: Fraktsiia narodnoi svobody. "Voennyia" sessii 26 iiulia 1914 goda-3 sentiabria 1915 goda (Petrograd, 1916). p. 32.

14. Rech', Aug. 7, 1915.

15. See Michael Cherniavsky, ed.. Prologue to Revolution: Notes of A. N. Iakhontov on the Secret Mectings of the Council of Ministers, 1915 (Englewood Cliffs, N.J., 1967), pp. 184, 242. The number of strikes in Moscow and Petrograd did increase significantly in response to the prorogation of the Duma.

16. P. N. Miliukov, Istoriia vtoroi russkoi revoliutsii, 3 vols. (Sofia, 1921-24), vol. 1 , pt. 1, p. 27, and Utro Rossii (Moscow). Sept. 6, 1915. 
In August 1915 the Bloc bluntly condemned the government for its divisive policies of discrimination and repression. It demanded above all a ministry of public confidence, but the government responded by prematurely adjourning the session. When the Duma was finally reconvened for four months beginning on February 9, 1916, the Bloc surprisingly failed to pursue what had been its chief objective in 1915. The most dramatic manifestation of this change in tactics came during March when, confronted with intensified persecution of the Jews, the Bloc was forced to take a stand on a vote to interpellate two state officials who had been involved in circulating directives implying that Jews were sabotaging the war effort and that therefore, as a group, they should be treated as traitors. ${ }^{17}$ The Bloc's program contained the cautious demand for the "entry upon the path" of abolishing restrictions on Jews, including "further steps" toward abolishing the Pale of Settlement, the reopening of the Jewish press (which had been closed down by the military censor, leaving thousands of Jews who could not read Russian or Ukrainian without written sources of information), and greater access to education and the professions. These demands, weak as they were, had been included only as a concession to the Kadets and remained controversial. Although most Jewish leaders expected Bloc fidelity to its stated principles, after much vacillation the coalition refused to support the interpellation. Moreover, while Jewish deputy $\mathrm{M}$. Bomash was approaching the Duma tribune for the purpose of withdrawing the interpellation, Count D. I. Kapnist, in the name of the Zemstvo Octobrists, announced that they would not support the interpellation for the sake of "internal peace." It was not the government that incited one part of the population against another, he contended, but rather the Duma, because it raised the Jewish question. To this, Social Democrat A. I. Chkhenkeli exclaimed: "The Progressive Bloc is dead ; long live the regressive Bloc."18

The incident enraged all segments of Jewish society. A spokesman for the Jewish Democratic Group. which generally supported the Trudoviks but which had looked favorably upon the Bloc, now referred to the Bloc as a "cloak for current government policies." He went on to say, "Intended as an instrument to accommodate the government to society, it has become a means of accommodating society to the government." ${ }^{19}$ Zionist I. Grinbaum believed that as Russian liberals began to respond to concrete political issues they abandoned

17. A more thorough examination of this incident and its repercussions may be found in Michael F. Hamm, "Liberalism and the Jewish Question: The Progressive Bloc," Russian Revicw, 31, no. 2 (April 1972): 163-72.

18. Gosudarstvennaia Duma: Stcnograficheskie otchcty. 1906-17 (Petrograd, 1906-17), session IV, meeting 34, columns 3142-46, her eafter GDSO.

19. Grigorii Landau, Novyi put' (Moscow), Apr. 24, 1916. 
their "principled idealism" in the process. ${ }^{20}$ Even the "organ of Jewish Kadetism," Evreishaia nedelia, reproached the Kadets for sacrificing the most rudimentary needs of Jews for the sake of maintaining the coalition with Duma conservatives. ${ }^{21}$ On June 7, 1916, the Jewish deputy M. Fridman, a Kadet, angrily disaffiliated himself from the Bloc, protesting against continued efforts to exclude Jews from the benefits of legislation and against the record of the Duma, which he characterized as one of evasion of the question of Jewish rights and of imposing even more restrictions upon the Jews. ${ }^{22}$ Rech' insisted that the incident had not been a "violation of fundamental political tasks." but merely a tactical mistake. ${ }^{23}$ But in essence the Bloc, through its inaction, sanctioned both inequality for and persecution of Jews. Its paramount demand had been that the govermment cease its policies of discrimination and division for the sake of national unity during the war. In refusing to support the interpellation, which marked an ideal opportunity to excoriate these governmental policies, the Bloc indicated that it no longer stood behind its demand for a government that enjoyed the confidence of all the citizens of the empire.

Furthermore, the incident reflected more than the highly emotional nature of the Jewish question. The Bloc failed to pursue any of the innocuous nationalities planks in its platform. Indeed, just prior to the March incident the Bloc helped pass a resolution ending a debate which criticized the government for failing to combat high prices, and which contained a reference to a traditional scapegoat of the Right, "German influence."24 The Bloc refused to support Chkhenkeli's attempt to insert the phrase "so-called" before "German influence," thereby sanctioning placement of partial responsibility for high prices on a national minority scapegoat.

Once the situation at the front stabilized in the winter of 1915-16, the panic which had forged the Bloc quickly dissipated. Consequently, because of the absence of strong ideological unanimity, Great Russian nationalism grew stronger as a common bond for unity within the coalition. The issue of fair treatment for national minorities became untimely. Moreover, the demand for a government which could command confidence throughout the empire, deemed so critical the preceding summer, all but disappeared from the political scene until November 1916.

By the time the "long session" opened on February 9, 1916, B. V. Shturmer had replaced Goremykin, although this constituted little improve-

20. Eureiskaia zhizn' (Moscow), Apr. 3, 1916, p. 49.

21. See Evrciskaia nedelia (Moscow), during May 1916.

22. GDSO, IV /52/4883-89.

23. Rech', Mar. 11 and Apr. 10, 1916.

24. GDSO, IV $/ 33 / 3012-14,3024$. 
ment, if any at all. Nevertheless, during this session which ran until June 20, the Bloc tacitly turned its collective attention to its legislative program, promotion of which became its main raison d'être. In sum, the coalition succeeded in winning passage for several major bills, including a graduated income tax and bills regulating cooperatives and censorship reform. Most of the Bloc's conservatives, as well as many Kadets and Left Octobrists, regarded this as a productive and satisfying session. But the more militant Kadets and the majority of the Progressists were disappointed. Even though it controlled key Duma committees, the Bloc had failed to get most of the "headline" bills, particularly those dealing with reform of local government institutions, out of their respective committees.

For example, the Bloc spent many hours debating the details of its stated commitment to reform municipal government institutions and, most important, the Municipal Statute of $1892 .{ }^{25}$ City governments were denied the necessary means to cope with their legal responsibilities during the period of rapid urban growth between 1892 and 1914. World War I brought even greater burdens to municipal government, including caring for the wounded and for refugees, combating epidemics, and organizing supplies of food, fuel, and other necessities. Union of Towns officials, many of them Kadets, encouraged the Bloc to improve the situation by means of statutory reform. Hence, in the name of wartime necessity, the Bloc worked out a bill containing some two hundred articles. Among the most important were those intended to alleviate the financial plight of the cities, professionalize municipal administrations, and terminate the stifling bureaucratic interference by the state which curbed local initiative and made local institutions all the more ineffective. In May 1916 one journalist noted that the issue of municipal reform was the "trial swim" for the Bloc-the only "headline" project other than the income tax bill that attracted wide attention. ${ }^{26}$

Yet the Bloc failed to bring the bill out of its committee because it divided over the issues of how far to extend the franchise and whether to use a restrictive curial system of voting. Originally based on the Prussian threeclass system, the curial system in Russian towns had been altered by the Municipal Statute of 1892, which based the franchise on a high property qualification and thereby reduced the franchise so greatly that seldom was more than 1 percent of the urban electorate eligible to vote. ${ }^{27}$

25. For a good bibliography on Russian municipal government and the prospects for reform see "Ukazatel' literatury po voprosu ob organizatsii gorodskago samoupravleniia," in Izvestiia Moskovskoi gorodskoi dumy, no. 5, May 1916. See also A. I. Shingarev, "Zemskaia i gorodskaia Rossiia," in Chego zhdet' Rossiia ot voiny (Petrograd. 1915).

26. D. Protopopov in Rech', May 19, 1916.

27. The 1870 Municipal Statute had based the franchise on payment of taxes. The 
The Kadets, though they refrained from demanding universal suffrage, insisted on both a small expansion of the electorate and general, or noncurial, municipal elections. Bloc conservatives supported the former but not the latter. The Progressists vacillated, although they ultimately decided to sacrifice their principles and sided with the conservatives in the hope of getting the bill through the Duma. Governors from the central gubernii, meeting at Sevastopol in May 1916, in summarizing conservative opinion contended that the Kadet scheme would be dangerous for the state, for it would turn city government into a political body for the "third element." ${ }^{\text {"28 }}$ Conversely, Kadet M. M. Novikov warned that retaining the curial system would further discourage Russia's educated elite from participating in municipal government because of the continued hopelessness of achieving constructive goals within the system. ${ }^{29}$ In Rech', commentator D. Protopopov argued that it was better to defer the entire electoral question until a later time than to pass a bill with a curial system. ${ }^{30}$ Protopopov failed to mention that the main justification for any bill at all in 1916 was its alleged pertinence to the war effort; how then could the bill be deferred?

The municipal bill therefore remained in committee, because the other Bloc caucuses rejected Kadet attempts to realize a traditional liberal political goal, but one which had little relevance to the war effort. Also, attempts to legislate the creation of a zemstvo at the volost level had little wartime pertinence, because, as Nationalist deputy D. N. Chikhachev estimated on December 13, 1916, after allowing time for the Duma and the State Council to pass the bill, and assuming smooth implementation, the very earliest that a zemstvo could function would be the summer of 1917. Even then, shortages of qualified personnel, together with electoral restrictions, would seriously impair the efficacy of the organ..$^{31}$ Introduction of the zemstvo into the Caucasus and other outlying regions, another Kadet goal which appeared in the Bloc program, also had little immediate importance as long as many of these areas lay under military administration. Finally, the Bloc devoted most of its time during the last weeks of the long session to debating Duma approval for several of

1892 act eliminated the small property owner, the entire third curia established by the 1870 law. In some provinces in the Pale of Settlement the 1892 act disenfranchised 90 percent of the existing urban electorate. For an analysis of its impact see G. I. Shreider, "Gorodskaia kontr'-reforma 11 iiunia 1892 g." in Istoriia Rossii v XIX veke (Moscow, n.d.), vol. 5.

28. "Soveshchanie gubernatorov v 1916 godu." Krasnyi arkhiv, 33 (1929): 163. 13-14.

29. Izvestiia Vserossiiskago soiuza gorodov (Moscow, October 1916), no. 37, pp.

30. Rech', May 19, 1916.

31. GDSO, V/15/1039. 
Stolypin's decrees regarding peasant rights, already in effect by means of Article 87 of the Fundamental Laws. ${ }^{32}$

In assessing the Bloc during the first year of its existence, it must be acknowledged that the coalition surpassed the prediction made in 1915 by the independent Duna deputy M. A. Karaulov. "Fire and water cannot unite for peaceful work," he noted with reference to the diversity of opinion in the coalition. "From them there can only arise hot air."33 The Bloc held together, passed several major bills that had previously been stalled, and continued to muster support for the less controversial parts of its program in the conservative State Council. But the long session also marked the visible demise of the critical goal of 1915, the creation of a ministry of public confidence and administrative competence. In addition, as the issue of the municipal franchise illustrates, the more significant parts of the Bloc's legislative program foundered on old political differences. The Zemstvo Octobrists and other Bloc conservatives regarded basically political issues such as municipal suffrage as untimely. In reality such issues were not germane to the war effort and served only to divide the coalition and stifle work on more relevant problems. Furthermore, the Bloc avoided many key issues, at least in terms of their urgency-above all those dealing with the soaring cost of living. For example, the Bloc devoted very little time to championing the demands of the urban worker, whose wage increases generally lagged far behind the rate of price inflation.

In fact, in my opinion, even if implemented fully in mid-1916 by the Duma or by Article 87 , the Bloc's program would not have been sufficient to placate the weary, volatile masses. Hypothetically, if the Kadets and Progressists had been able to impose their own ideals, which included a constitutional, democratic order, this would have been a different matter. But in reality the liberals could not even fully impose their diluted wartime aspirations, as stated in the Bloc's program, on the coalition's conservatives, who in turn lost much of their zeal once the panic of the summer of 1915 subsided.

I therefore cannot agree with Thomas Riha's assertion that "the monarchy's last real chance for survival had been missed in the calmer days when discussion was still possible." ${ }^{34}$ Abandonment of the pursuit of fair treatment

32. Article 87 enabled the government to pass "emergency" laws when the Duma was not in session. The government often abused this right, and during the war implemented most laws in this fashion. During the fall of 1916 many Bloc members, including the conservatives, wanted to reject all laws enacted by Article 87 which did not pertain to national defense. Time prohibited this, but the issue remained symbolic of the rift between the Duma and the government.

33. GDSO, IV $/ 15 / 1152-53$.

34. Thomas Riha, "Miliukov and the Progressive Bloc in 1915: A Study in Last Chance Politics," Journal of Modern History, 32, no. 1 (March 1960): 24. Riha is referring to the period of the Bloc's formation, August 1915. 
for national minorities, the inability to win even small liberal political concessions in the debate over local government reform, and the failure to confront pressing questions, such as inflation, indicate that the Bloc was ill-suited to implement the reforms necessary to save the monarchy. If the government had adopted the Bloc's program in 1915 or 1916, it would have made little difference, because most of the program was irrelevant to current needs. And even if Nicholas II had consented to a "ministry of confidence," this would certainly have included a majority composed of moderate bureaucrats, Zemstvo Octobrists, and Progressive Nationalists and not Kadets, Progressists, or Socialists. In view of the performance of the conservatives in the Duma, it is unlikely that such a ministry would have taken bold new initiatives appropriate to the times.

Nor do I agree with Riha's contention that the January 1915 session was the last in which the government was faced with a passive opposition. ${ }^{35}$ The Bloc remained passive during the long session in 1916. It had the weapon of the word, but it remained verbally timid. The Bloc's political posture remained less militant than even the supposedly nonpolitical War Industry Committees, which at their Second Congress in February 1916 accepted a resolution calling for cabinet responsibility before the Duma. Rech' warned that such resolutions would destroy the unity of the "public movement." ${ }^{\text {s }}$ In reality the small step toward a democratic order noted by Kornilov was not only insufficient to assuage the anger of the workers, it was not strong enough to maintain the unity exhibited by the moderates during the summer of 1915 . In mid-1916 Union of Towns leader M. V. Chelnokov, a Kadet, tacitly indicated the inadequacies of the Bloc when, after recalling the apolitical origins and objectives of the Union, he admitted that the "instinct of self-preservation" compelled the Union to turn to political activism. ${ }^{37}$ If Nicholas and Goremykin dashed the original hopes of the Bloc, the coalition did little in 1916 to convince society that its early expressions of hope in the Bloc had been justified.

By the time the Fifth Session of the Duma opened on November 1, 1916, legislative matters gave way to new cries of alarmism and furious debates over the critical question of the provisioning of food and fuel-an area, ironically, in which the Duma had little competence. Deteriorating economic conditions, frustration with the war, Duma passivity, and governmental ineptitude combined to result in a new wave of unrest. Soviet historian I. P.

35. Ibid., p. 17.

36. See Trudy vtorogo $s^{\prime \prime} e z d a$ predstavitelei voenno-promyshlennykh komitetov 26-29 fev. 1916 (Petrograd, 1916), pp. 625-26, and Rech', Mar. 7, 1916.

37. BNFR, pp. 88-89, and Izvestiia Vserossiiskago soiliza gorodov, no. 33, pp. 86-87. 
Leiberov notes the appearance in Petrograd of the all-city political strike in October 1916, as well as in January and February 1917. During the period from September 1916 until the February Revolution there occurred 146 more political strikes, with 164,000 more strikers, than had occurred during the entire twelve months prior to September 1916 in Petrograd. During this same period the ratio of political to economic strikes was roughly $3.3: 1$, while during the preceding twelve months the ratio had been about $2: 3 .^{38}$ The War Industry Committees' Labor Group, as its Menshevik leader K. A. Gvozdev admitted, had not been successful in developing close ties with the majority of the workers ${ }^{39}$ and despite the unrest an apparatus to arbitrate and rectify labor grievances still did not exist.

Several Bloc leaders, especially the Progressists Efremov and Konovalov, had cautioned about the revolutionary potential of the workers at least since the days of the Bloc's formation. For the liberals, revolution risked sabotaging the war effort. In addition, Miliukov believed that an insurrection could not easily be controlled and could result in anarchy. If revolution broke out, Miliukov predicted that it would become that "terrible Russian bunt, mindless and merciless, which terrified Pushkin." 1916 did a majority of Bloc leaders become preoccupied with the fear of revolution.

Despite these fears, the Bloc's posture remained flaccid. Its activities did not differ significantly from those of the preceding spring, though the oratory became a bit sharper. Although on November 1 Miliukov delivered his famous "stupidity or treason" diatribe, implying that government officials were probably guilty of both, the coalition's formal declaration, which noted that a lack of confidence had given way to a "feeling close to indignation," paled by comparison. ${ }^{41}$ In fact, despite the atmosphere of crisis, the chasms within the Bloc seemed to grow wider. The conservative groups demanded that the Bloc emphasize the positive side of the picture, for example Russia's abundance of resources. Even so, half of the Centrists refused to pledge open support for the Bloc despite the inclusion of a degree of optimism. The rest of the

38. My computations are based on statistics compiled by I. P. Leiberov, "O revoliutsionnykh vystupleniakh petrogradskogo proletariata $\mathrm{v}$ gody pervoi mirovoi voiny $\mathrm{i}$ fevral'skoi revoliutsii," Voprosy istorii, 1964, no. 2, p. 65. For an analysis of the strike movement in Moscow see G. G. Kasarov. "Stachechnoe dvizhenie v Moskve v gody pervoi mirovoi voiny (19 iiuliia 1914-25 tevralia 1917 g.)," Vestnik Moskovskogo universiteta, 1970, no. 6, pp. 28-41.

39. V. S. Diakin, Russkaia burzhuasiia i tsarizm v gody pervoi mirovoi voiny, 19141917 (Leningrad, 1967), p. 199. Laverychev calls the labor group "social traitors" who were "colonels without an army" (Po tu storonu barrikad, p. 138).

40. BNFR, pp. 62-63.

41. GDSO, V/1/11. 
conservatives remained in the Bloc probably because they saw the coalition as the best means of preventing the government from signing a separate peace, a step which would have ensured the loss of large amounts of territory controlled by Octobrist and Nationalist landowners.

On the other hand, the Progressists formally withdrew because the coalition's tactics did not reflect the gravity of the situation. Since June 1916 they had not participated at Bloc meetings, remaining divided over whether to stay in the coalition. Now they began to reiterate the urgency of creating cabinet responsibility before the Duma. Efremov asserted that during the war the country and army had "more strongly and fanatically believed in the Duma, believed in its omnipotence, and expected salvation from it." But now the country looked to the Duma with terror, for it was beginning to lose faith in the Duma's power, and was beginning to look to "other means." 42 To Efremov, creation of cabinet responsibility before the Duma could "accomplish a miracle."

There is some evidence that the Bloc came close to demanding cabinet responsibility publicly. On December 9, 1916, Progressist deputy A. M. Maslennikov told the Duma that he believed the entire Bloc would soon rally behind the demand for a parliamentary order. ${ }^{43}$ But the Bloc continued to shy away from demands for radical changes, calling only for vague innovations like a ministry "leaning on" (opirat'sia na) the Duma.

Why did the Bloc fail to adopt a more militant stance during these final months of social tension? First of all, from the beginning Bloc deputies had seen themselves as reconcilers and not initiators. They displayed a great fear of "forcing events," and hence refrained from illegal tactics like calling for assembly of the Duma without government permission. In mid-1915 Miliukov stated that if the Duma provoked an open conflict with the government, it would spark the "orgy of the mob." 44 This argument restrained many Kadets who otherwise felt 'uneasy with the "unnatural" alliance with the Duma's conservatives.

Fearing open conflict with the government, the Bloc therefore avoided both militant tactics and aggressive oratory during the long session. Furthermore, early in the session Miliukov told the Duma he would rather not organize Russia if he knew it would lead to revolution and defeat. ${ }^{45}$ Hence

42. Ibid., $\mathrm{V} / 19 / 1315-16$.

43. Ibid., V/14/997.

44. BNFR, pp. 62-63. It should be noted that the Progressists were less fearful of forcing events and less willing to compromise with the government than the other Bloc groups. For this reason the Progressists were never comfortable with their role as a participating group in the coalition.

45. GDSO, IV/31/2797-2814. 
the Bloc also avoided demanding reforms of contemporary pertinence, particularly those that night raise the hopes of the workers. For if the promise of such reforms went unfulfilled, the anger and frustration of the workers would increase even more. In short, as long as the specter of anarchy loomed in the background, the Bloc's majority believed that firm government, even if it was bad government, was more than ever a dire necessity. ${ }^{46}$

A less important factor was the periodic though unrealistic hope that the government would actually create a liberal ministry. V. S. Diakin contends that by the spring of 1916 the liberals realized that their efforts to organize the masses under bourgeois leadership and through bourgeois organizations such as the War Industry Committees were doomed to failure. Therefore, with nowhere else to turn, Bloc liberals could more easily cling to their policy of collaborating with the conservatives in the hope that the rising militancy of the working class would force the government to create a ministry of Kadets and Progressists. There is evidence to support Diakin's view. For example, Konovalov believed that if the Bloc became more aggressive in its tactics, a government of "Miliukovs and Shingarevs" would draw nearer and the November session would become the "final assault" on the bureaucracy. ${ }^{47}$ In addition, Diakin's argument helps explain why the Kadets continued to adhere to their tactic of strictly legal pressure on the government during the tense months of January and February 1917. Even so, most liberals were seldom optimistic about their chances for a role in the government, especially after August 1915 ; and at one point, on November 21, 1916, Rech' rejected these hopes as "naive."

Is Diakin's view correct that the "great majority of bourgeois leaders [were] organically incapable of moving in the direction of even the limited desires of the defensist wing of the labor movement, those who sought class peace" and cooperation ?48 A complete answer would entail a thorough study of the Special Council on Defense, which had the authority to review and alter wages and prices, and the public organizations, as well as the Bloc. But the record of the Bloc, its passivity and its failure to use the Duma even as a forum to champion the needs of the working classes, seems to support this contention. The Bloc manifested little ideological opposition to the economic and organizational desires of the workers-wage increases and a lifting of restrictions on union activities. But Bloc deputies, whether liberal or conservative, also feared the workers; hence they abstained from cham-

46. BNFR, pp. $62-63$.

47. See Diakin, Russkaia burzhuaziia, esp. pp. 179, 249, 292-97. See also Russkiia vedomosti, Jan. 11, 1917, and B. B. Grave, $K$ istorii klassovoi bor'by $v$ Rossii $v$ gody imperialisticheskoi voiny (Moscow and Leningrad, 1926), pp. 357-59.

48. Diakin, Russkaia burzhuaziia, p. 178. 
pioning such issues or doing anything that might "force events," or in other words encourage the worker to become more aggressive in his political behavior.

On the other hand, the record of the Bloc, together with the absence of evidence to indicate that the Bloc had a secret strategy to deal with the eventuality of revolt, casts doubts on Laverychev's belief that an important reason for the Bloc's formation had been to avert revolution. ${ }^{49}$ In 1915 most Bloc deputies seemed to believe that the great majority of workers were "patriotic" and willing to continue to sacrifice for the war effort. Nevertheless, while the Bloc appealed to this patriotism, it simultaneously avoided dramatic tactics-such as petitioning Nicholas II instead of Goremykin-and worded its declarations carefully in order to ensure that they would not be interpreted as ultimatums or as calls to arms. Only the Progressists seemed to chafe under these tactics.

During 1916, despite the strikes and the increasing alarmism of the Progressists and Kadets, the Bloc's conservatives appeared to maintain this view. Strikes were disruptive, but they were not revolution. Konovalov aside, for most of the Bloc what was essential was that the coalition avoid any tactic that might promote-or catalyze revolution. Miliukov noted that only a small minority of workers opposed the war on principle. In fact, at times he showed more concern about the postwar internal situation and stated that the war alone kept tensions from boiling over. ${ }^{50}$ And as worried as Utro Rossii was about the anger of the present, its November 10, 1916, editorial indicated greater concern about what the worker's mood would be after the war, when wages were likely to fall and strikes were likely to retard postwar economic recovery. This attitude, I believe, further convinced the Bloc to refrain from acting aggressively and "forcing events" and no doubt was at least partly responsible for the fact that the Bloc's legislative program seemed to devote more attention to the future than to the present.

In mid-1915 the Duma's liberals and conservatives came to believe that the central need was that of unity throughout the empire and reconciliation between government and society. Chaos at the rear risked dissipating the morale and the conficlence of the army. It was therefore imperative that the

49. As I have already pointed out. Konovalov and a few others feared the possibility of a revolutionary situation during the summer of 1915. But there is little evidence among the police reports and Bloc documents to indicate that this fear was pervasive in 1915 or that the Bloc was created as an antirevolutionary front. Laverychev acknowledges that such evidence is lacking but believes that recollections included in various émigré memoirs sufficiently support his view. See Laverychev, Po tu storon barrikad, esp. p. 121.

50. GDSO, V/21/1520, V/20/1337, and BNFR, p. 147. 
representatives of the country unite in a common spirit around a positive program. The government never joined this front but instead waged a systematic campaign to destroy it. But, in addition, the record of the Bloc indicates that on sensitive issues, unity and the sense of urgency quickly dissolved.

In a sense the indecision of the Bloc reflected the indecision and disunity of the moderate and liberal movements in general. Inside and outside the Duma both the Kadets and the Progressists remained divided over tactical questions throughout 1915 and 1916. The latter achieved unity more easily on a negative issue-withdrawal from the Bloc on November 1, 1916-than on any positive, alternative strategy. Even so, on November 1 Russkiia vedomosti noted that the Progressists were still divided over the wisdom of this move, and two days later Utro Rossii admitted as much. Outside the Duma, the fact that P. P. Riabushinsky was compelled to resign from the Moscow Stock Exchange Committee on December 2, 1916, indicated that among his peers opposition to the man who symbolized the activist "radical" wing of the Moscow Progressist group was growing stronger.

In addition, the Bloc never fully overcame the obstacle of the State Council or the tsar's ability to control that body by means of his powers of purge and appointment. The bill on cooperatives, passed by the Duma in March 1916 and deemed an important means of counteracting economic disorganization, still had an uncertain fate in the Council on the eve of 1917. In November 1916 the Council began to weaken the bill by removing several kinds of cooperatives from its jurisdiction. As one cooperative organ noted, the absence of a single juridical basis for cooperatives destroyed the chance for an effective cooperative movement throughout the country. ${ }^{51}$ In general, while Council members raged at government incompetence, few showed much legislative or reformist zeal.

The Bloc did maintain some value as a focal point for the coordination of public forces, although this seemed to wane in 1916, and some value as a watchdog over the government. In the words of one editorial. "We forget that the significance of parliament is not so much in the good it can do as it is in the evil it can prevent." 52 Without the Bloc the public organizations would have been hindered even more in their activities, the workers and their organizations would have suffered even greater oppression, and the spirit of the country and the army would have flagged all the more. As one unnamed Social Democrat put it in February 1917, "The Duma and its bourgeois deputies

51. Soins potrebitelei (Moscow), no. 37, Nov. 10, 1916, p. 1371. For a discussion of the unprecedented defection from a progovernment position by rightist members of the Council see Birzhevyia vedomosti (Petrograd), Nov. 27 and 28, 1916.

52. Gorodskoe delo (Petrograd), no. 21, Nov. 1, 1915, p. 1105. 
are not necessary for the worker, but the atmosphere of the Duma is, for it gives the worker the opportunity to breathe a little easier."53

Perhaps Progressive Nationalist leader V. V. Shulgin summarized the Bloc's position best: "We need to fight, for the government consists of scoundrels. But since we do not intend to move to the barricades, we cannot egg others on. The Duma must be a safety valve which lets off steam and not one that creates it."54 In November 1916 Miliukov's "stupidity or treason" speech produced great excitement among the laboring classes and at the front, where it was clandestinely distributed. After the speech Konovalov observed that the "ugly" mood of the Petrograd workers momentarily improved. Apathy -or lack of productivity-disappeared. Workers in the factories debated how to react to Miliukov's speech and rejected a one-day sympathy strike. Instead they decided to adopt a wait-and-see position in anticipation of further Bloc moves. ${ }^{55}$ In this case the Duma served to "let off steam." But the rest of the Bloc maintained a timid posture and adopted its own wait-and-see strategy with the newly appointed Trepov. In short, except during August 1915, the Bloc refused to allow the Duma to become a safety valve. Miliukov and the Bloc liberals continued to demand that only the Duma, and no other organization or group, dictate the conditions of struggle with the government. But in refusing to use the Duma as a forum to champion genuinely popular and pertinent causes, the Bloc failed to use the Duma effectively.

Although it originally had stood for change and unity, the Bloc, because of its political passivity and its failure to confront the needs of the present, became identified with the status quo. It did not attempt to initiate changes appropriate to the needs of the time; it therefore could not reconcile or unify. Shingarev believed that the Kadets-and the Bloc-were trapped between a desire to condemn the government and the need to maintain national unity during wartime. In reality, strong condemnation was a prerequisite to national unity. But as a tactic this risked the very existence of the Duma and risked fomenting anarchy as well. In sum, the majority coalition of the Fourth Duma may have delayed the eruption of a volatile social situation, but it did little to improve that situation in any fundamental way.

53. $B N F R$, p. 173.

54. "Blok," Krasnyi arkhiv, 56 (1933) : 114.

55. Ibid., p. 122, and $B N F R$, pp. 139-42. 